\title{
ESTABLISHING EX SITU CONSERVATION METHODS FOR DACTYLORHIZA EBUDENSIS AND D. TRAUNSTEINERIOIDES, A COMBINATION OF IN SITU TURF REMOVAL AND IN VITRO GERMINATIONS
}

\author{
Berta Millàs Xancó ${ }^{1}$, Jaime Aguilar V $V^{2}$, Gregory J. Kenicer ${ }^{3} \&$ Heather McHaffie ${ }^{4}$
}

\begin{abstract}
Orchidaceae is one of the most diverse flowering plant families in the world, occupying a diverse range of habitats from epiphytes to terrestrial forms. It is also one of the most vulnerable to changes in land use because of its complex ecological requirements. In nature, orchid seed will only grow if infected with a compatible fungus which provides all the carbohydrates and nutrients needed for its development. This mycotrophic mode of nourishment can persist underground for years in some orchids, which makes them difficult to observe in the wild. Understanding their behaviour is essential for their successful propagation and conservation. In an investigation looking into conservation and propagation, turves were lifted from wild populations of two rare Scottish orchid species in order to ensure the best possible association between these species and their growing environment. A combined in vitro experiment was set up for the wild harvested seeds under different media to compare their effects. Two different successful ex situ conservation methods for Dactylorhiza ebudensis and D. traunsteinerioides are presented.
\end{abstract}

\section{INTRODUCTION}

Orchidaceae is the most species-rich plant family and undoubtedly one of the most horticulturally important - orchids fascinate and delight many people (Cribb et al., 2003). The key elements responsible for this enormous diversity are their ability to hybridise, their often tight pollination syndromes with specific invertebrate partners and mycorrhizal associations with specific fungal partners (Bonnardeaux et al., 2007; Waterman $\&$ Bidartondo, 2007). These same traits of specialisation in pollinators and in fungal partners also contribute to the rarity of many species (Swarts et al., 2010). Orchid seeds are produced in large quantities, they are minuscule (often referred to as 'dust-like') and they have very small food reserves to fuel germination. In nature, they will not grow unless supported by a suitable fungus, which provides all the carbohydrates and nutrients needed until the plants are large enough to become autotrophic. This nutritional system, referred to as mycotrophic, is obligate during germination and early seedling stage but

1. Berta Millàs Xancó is a graduate in Horticulture with Plantsmanship BSc (Hons) at the Royal Botanic Garden Edinburgh. Address: 20A Inverleith Row, Edinburgh EH3 5LR.

Email: berta_millas@hotmail.com

2. Jaime Aguilar is an orchid micropropagator technician and leader of the project ad honorem.

Email: jaguilaruk@gmail.com

3. Gregory J. Kenicer is Head of Education at the Education Department at Royal Botanic Garden Edinburgh.

Email: gkenicer@rbge.ac.uk

4. Heather McHaffie is Conservation Officer at Royal Botanic Garden Edinburgh.

Email: H.McHaffie@rbge.ac.uk 
becomes supplementary in most green orchids when they start producing their own food by means of phototrophy (Rasmussen, 1995). Furthermore, orchid-fungal relationships are dynamic through the life of the plant (Bidartondo \& Read, 2008), with the fungus that promotes germination not necessarily persisting as the later mycorrhizal associate. These levels of interdependency make orchids very sensitive to changes in their natural environment (Bundrett, 2007), and can make propagation and cultivation particularly challenging. Habitat loss and changes in land use have caused decline and extinction in many wild populations (Swarts \& Dixon, 2009). This also makes orchids valuable bioindicators, with their disappearance in a habitat being an indication of further-reaching, below-ground ecological change. Understanding these relationships is fundamental to our ability to propagate and cultivate these orchids for ex situ collections and inter situ conservation programmes (see Burney, 2009 for a description of inter situ conservation).

In the laboratory, orchids can be grown from seed by two different methods: asymbiotically, which makes use of a recipe that contains all the sugars, nutrients and vitamins in a form readily available to the orchid seed, and symbiotically, which uses a simpler recipe, low in carbohydrates and inoculated with a suitable fungus to aid germination and support seedling development. Whilst many tropical epiphytic orchids can be successfully micropropagated by asymbiotic techniques, temperate terrestrial orchids have remained rather difficult. The latter seems to be more successful using symbiotic techniques, especially for rare British orchids (Mitchell, 1989; Muir, 1989). One reason is because temperate terrestrials are more dependent on mycorrhizal associates than their epiphytic counterparts (Yoder et al., 2000). They germinate in the dark and can remain white underground even for years supported mycotrophically (Rasmussen, 1995). Epiphytic orchids, in contrast, germinate in the light with no dormancy and with a green protocorm they start to photosynthesise at a very early stage. Symbiotically propagated plants develop more quickly and seem to be healthier and stronger compared to asymbiotically propagated plants, making them ideal for reintroduction programmes (Mitchell, 1993; Seaton et al., 2012). Rasmussen \& Whigham (1993) and McKendrick (2000) have

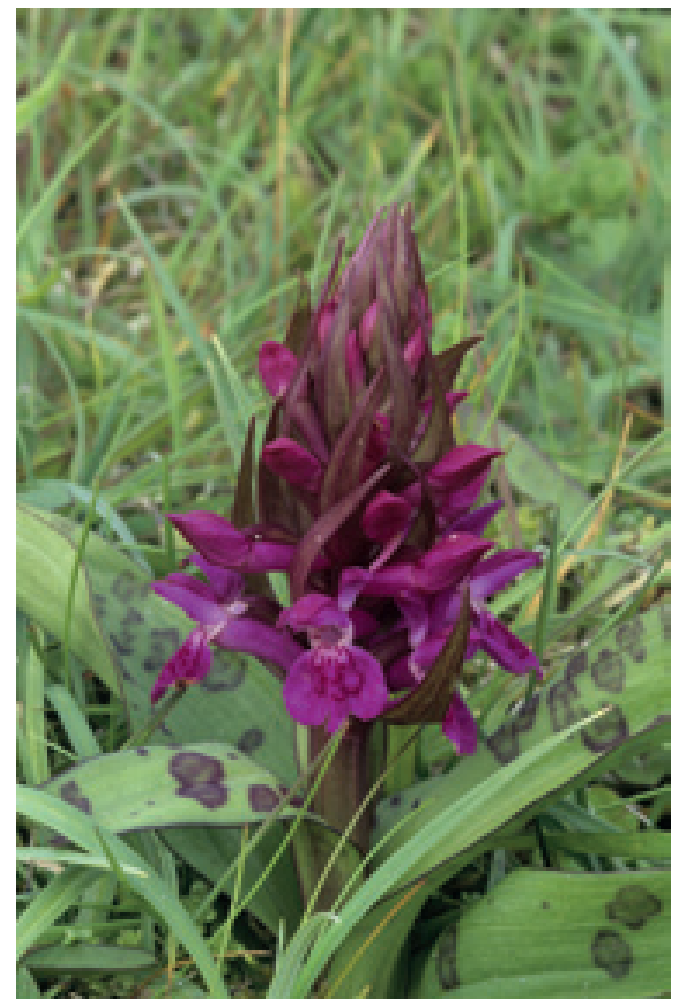

Fig. 1 Dactylorhiza ebudensis. Photo: Sidney Clarke. 
pioneered methods to understand the symbiotic behaviour in the wild and capture symbionts that can then be used in culture. These researchers used a seed-packet capture method in which orchid seeds are used as 'bait' for fungal symbionts. Specificity of fungal partner is thought to be one factor in the rarity of some terrestrial orchid species (Bonnardeaux et al., 2007; Waterman \& Bidartondo, 2007); consequently, it is important to capture and characterise the fungal partners in situ to successfully conserve them.

In the UK, there are 56 species of native orchids and around 70 in total, all of which are terrestrial. A third of these are considered threatened and ten species are protected under Schedule 8 of the Wildlife and Countryside Act (1981). There are four orchids endemic to the UK: Epipactis sancta, Dactylorhiza occidentalis, D. traunsteinerioides and D. ebudensis (Harrap

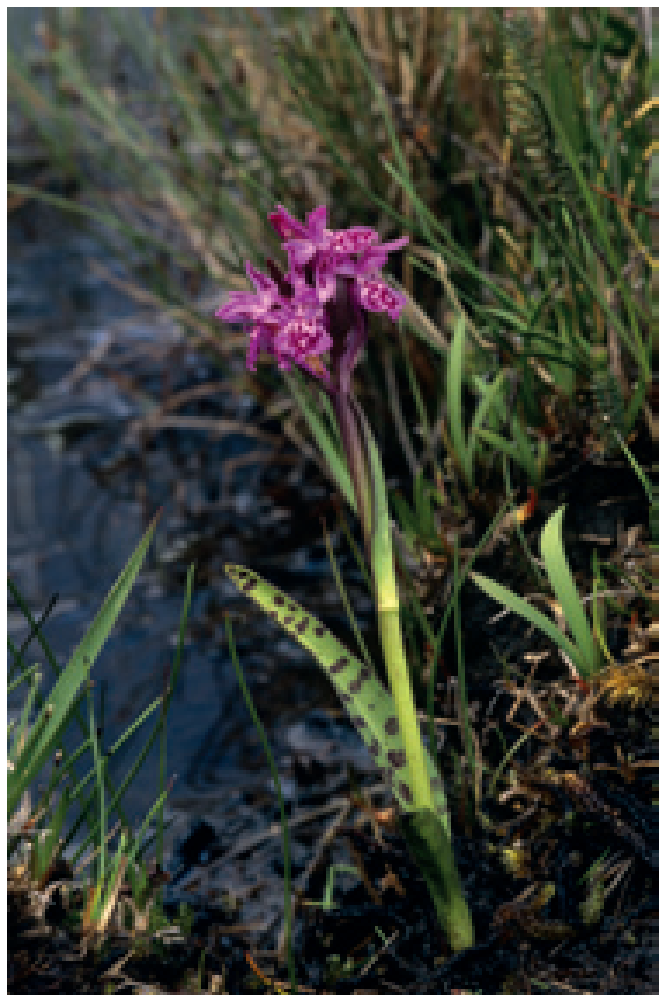

Fig. 2 Dactylorhiza traunsteinerioides. Photo: Sidney Clarke. \& Harrap, 2009).

D. ebudensis (Fig. 1) is found only in the Machairs of North Uist (see Fig. 4). These are a very specialised Atlantic coastal grassland characterised by cattle-grazed shelly, well-drained alkaline substrates with high levels of exposure and salt. Their populations are quite stable but because of its localised distribution, the species is considered vulnerable. D. traunsteinerioides (Fig. 2), in contrast, grows typically in wet fens raised by nutrient-poor and lime-rich springs. Their populations are scarce and very localised (see Fig. 5), being considered near-threatened, and they are protected under Schedule 8 of the Wildlife and Countryside Act (1981).

This paper reports on two methods for establishing ex situ conservation populations of these two species, including turf removal and in vitro germination of wild seed with universal fungal strains.

\section{TURF REMOVAL}

In order to ensure the best possible association between plants and their ex situ growing environment, turves (Fig. 3) were lifted from the wild in two sites for Dactylorhiza ebudensis, and three sites for D. traunsteinerioides (Table 1). 


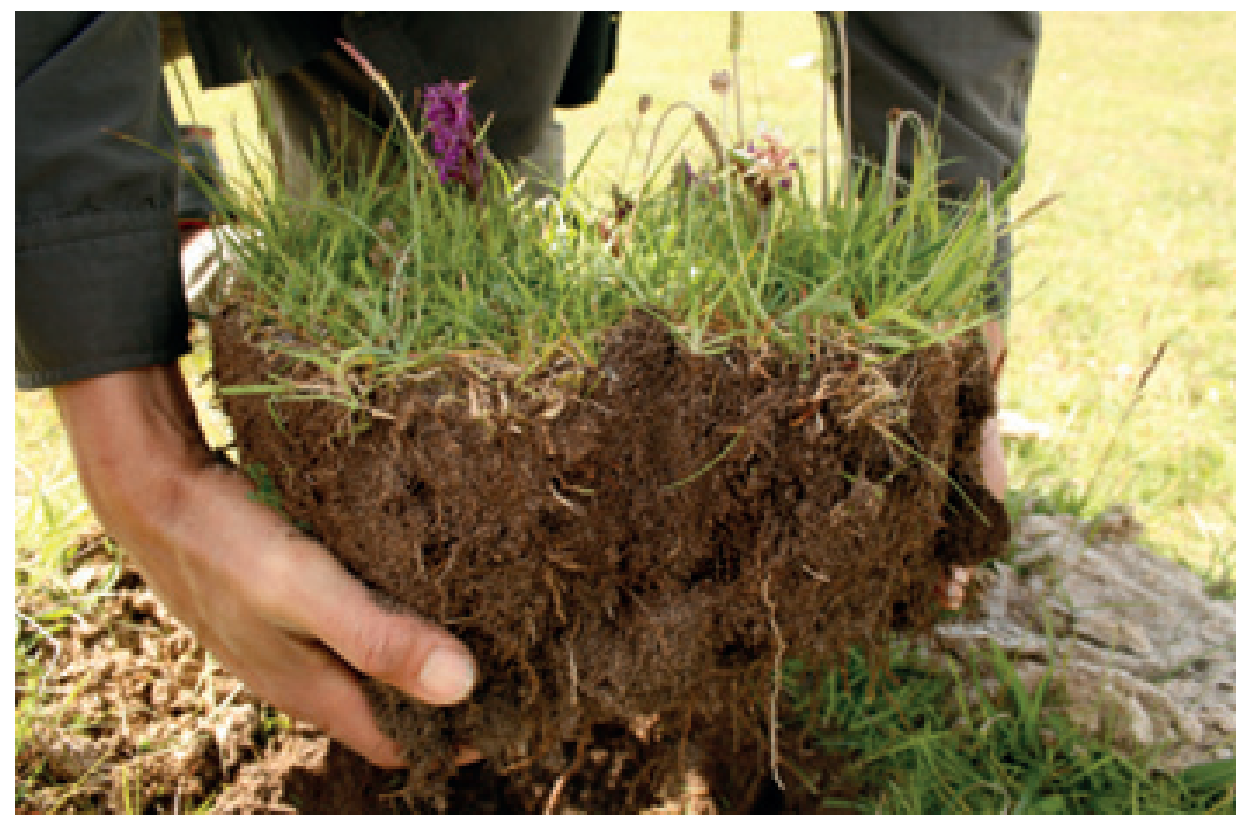

Fig. 3 Dactylorhiza ebudensis turf in Machair, North Uist. Photo: Berta Millàs Xancó.

All collecting permits and licences required were applied for in advance as follows:

- Consent from Scottish Natural Heritage (SNH) to remove plants of Dactylorhiza ebudensis from two Sites of Special Scientific Interest (SSSIs)

- Licence from SNH to uproot plants from Dactylorhiza traunsteinerioides, a species

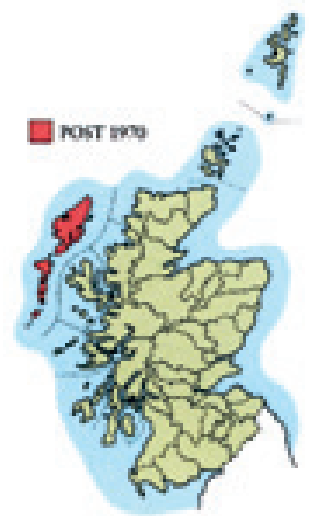

Fig. 4 Distribution map of Dactylorhiza ebudensis. 


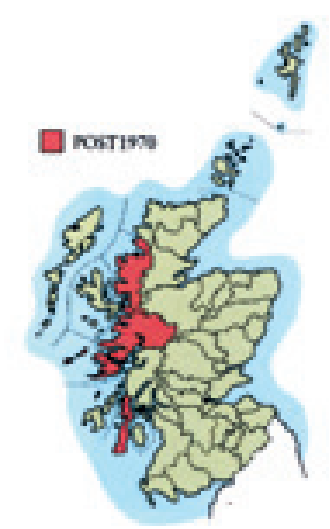

Fig. 5 Distribution map of Dactylorhiza traunsteinerioides.

protected under Schedule 8 of the Wildlife and Countryside Act (1981), from three different populations

- Permission from the farmers owning or renting the land

Population surveys were undertaken before any plant removal. Local experts were consulted to locate and identify the sites with the greatest number of individuals (aiming for 100 plants per population at least). No more than 10 per cent of the population was taken to ensure a minimum impact of uprooting in relation to the population size (Rae, 2006). All sites from which turves were harvested are considered to be stable and had large, representative populations.

Turves were dug out to a depth of $250 \mathrm{~mm}$ with a minimum radius of $100 \mathrm{~mm}$ from the basal rosette of each plant. Numbers of plant stems per turf varied depending on population density and ranged between one and four (Table 1). Following removal, turves were moistened and then packed in empty black compost bags for the return journey and wrapped up with mesh to prevent cross-pollinations between species.

On return to the Royal Botanic Garden Edinburgh (RBGE), the pH of each turf was measured, and each entire turf was potted up in Airpots ${ }^{\mathrm{TM}}$ (Single and Single, 2010), which allowed us to tailor the size of the pot to the turf, minimising root disturbance. The turves were jacketed with sphagnum, which retains moisture and is $\mathrm{pH}$-inert, and grit was used to fill the spaces between the sphagnum and walls of the pots. Pots were kept in a shade tunnel to allow exposure to rain and seasonal variations. Maximum care was taken to cultivate them as naturally as possible. Rainwater or water that had been standing in the open at least overnight was used to water the orchids. Vegetation surrounding the orchids was left undisturbed and trimmed regularly by hand to imitate grazing. Each plant was lodged on the $B G-B A S E^{\mathrm{TM}}$ database (Walter \& O'Neal, 1985-2010) and given an RBGE accession number. 


\begin{tabular}{|c|c|c|c|c|c|}
\hline $\begin{array}{l}\text { Accession } \\
\text { number }\end{array}$ & Orchid species & $\begin{array}{c}\text { Grid } \\
\text { reference }\end{array}$ & $\begin{array}{c}\text { Turf } \\
\text { number }\end{array}$ & pH & Location \\
\hline 20100819 & D. traunsteinerioides & NF579.419 & $\mathrm{T} 1$ & 6.3 & \multirow{3}{*}{$\begin{array}{l}\text { Druim an Aonaich, Isle } \\
\text { of Raasay }\end{array}$} \\
\hline 20100820 & D. traunsteinerioides & NF578.418 & $\mathrm{T} 2$ & 6.5 & \\
\hline 20100821 & D. traunsteinerioides & NF577.415 & $\mathrm{T} 3$ & 6.2 & \\
\hline 20100822 & D. traunsteinerioides & NF784.212 & $\mathrm{T} 4$ & 6.4 & \multirow{3}{*}{$\begin{array}{l}\text { Otter Haven Kylerhea, } \\
\text { Isle of Skye }\end{array}$} \\
\hline 20100823 & D. traunsteinerioides & NF784.212 & $\mathrm{T} 5$ & 6.3 & \\
\hline 20100878 & D. traunsteinerioides & NF784.212 & T6 & 6.3 & \\
\hline 20100879 & D. traunsteinerioides & NF374.659 & $\mathrm{T} 7$ & 6.2 & \multirow{5}{*}{$\begin{array}{l}\text { Totescore, } \\
\text { Scuddaburgh farm, } \\
\text { Uig, Isle of Skye }\end{array}$} \\
\hline 20100880 & D. traunsteinerioides & NF374.659 & $\mathrm{T} 8$ & 6.4 & \\
\hline 20100881 & D. traunsteinerioides & NF374.659 & \multirow[t]{3}{*}{ T9 } & \multirow[t]{3}{*}{6.4} & \\
\hline 20100882 & D. traunsteinerioides & NF374.659 & & & \\
\hline 20100883 & D. traunsteinerioides & NF374.659 & & & \\
\hline 20100884 & D. ebudensis & NF869.761 & \multirow[t]{4}{*}{$\mathrm{T} 10$} & \multirow[t]{4}{*}{6.6} & \multirow{6}{*}{$\begin{array}{l}\text { Cemetery at Druim na } \\
\text { Croise, } \\
\text { North Uist }\end{array}$} \\
\hline 20100885 & D. ebudensis & NF869.761 & & & \\
\hline 20100886 & D. ebudensis & NF869.761 & & & \\
\hline 20100887 & D. ebudensis & NF869.761 & & & \\
\hline 20100888 & D. ebudensis & NF870.761 & \multirow[t]{2}{*}{$\mathrm{T} 11$} & \multirow[t]{2}{*}{6.5} & \\
\hline 20100889 & D. ebudensis & NF870.761 & & & \\
\hline 20100890 & D. ebudensis & NF877.766 & \multirow[t]{2}{*}{$\mathrm{T} 12$} & \multirow[t]{2}{*}{6.6} & \multirow{4}{*}{$\begin{array}{l}\text { Cemetery onto the } \\
\text { Machair Robach, } \\
\text { North Uist }\end{array}$} \\
\hline 20100891 & D. ebudensis & NF877.766 & & & \\
\hline 20100892 & D. ebudensis & NF877.766 & \multirow[t]{2}{*}{$\mathrm{T} 13$} & \multirow[t]{2}{*}{6.5} & \\
\hline 20100893 & D. ebudensis & NF877.766 & & & \\
\hline
\end{tabular}

Table 1 Collection data for the species studied.

In order to obtain seed from each species, they were hand-pollinated using tweezers, in each case outcrossing between the turves. The turves were then protected with mesh to prevent further cross-pollinations. Capsules were marked with red ribbon and then harvested when mature - brown, but not dehisced, to avoid loss of seeds and minimise environmental bacteria or fungi spore contamination. Ripening times were taken from published guidelines. In the case of Dactylorhiza, the framework was between six and ten weeks (Harrap \& Harrap, 2009).

\section{Results}

Following two years of observation, the turves have established themselves well and there are currently fourteen stems (Table 2): eight of Dactylorhiza ebudensis and six of 
D. traunsteinerioides. This means an increase of six rosettes since 2011. The reduction in numbers from harvest to the first year of ex situ cultivation could be due to the stress of the move and/or the plants remaining in dormancy. The period from germination to flowering time for most Dactylorhiza is four or five years (Harrap \& Harrap, 2009) but this may vary subject to environmental conditions and soil nutritional levels (Vermeulen, 1947). The exact duration of the early underground stage remains unclear and can be varied between orchid groups (Rasmussen, 1995). Dactylorhiza spp. annually replace the underground tuber and roots by producing a new tuber that will sustain the next year's growth alongside the current one that will shrivel away gradually at the end of the season (Harrap \& Harrap, 2009). It is interesting to see the increase in numbers of individuals in turf 13 beyond the numbers originally harvested, with one emerging with completely purple-flushed foliage. The newly observed shoots probably represent individuals that were in a mycotrophic underground phase. It seems clear that the fungal partners remain present and healthy. The vegetation surrounding the orchids which is still present and managed also serves as an indicator that the microorganisms held in most of the turves have remained sustainable.

\begin{tabular}{|c|c|c|c|c|}
\hline & Turves & $\begin{array}{c}\text { Number of } \\
\text { individuals - harvest } \\
2010\end{array}$ & $\begin{array}{c}\text { Number of } \\
\text { individuals - } 2011\end{array}$ & $\begin{array}{c}\text { Number of } \\
\text { individuals - } 2012\end{array}$ \\
\hline $\mathrm{T} 1$ & \multirow{9}{*}{$\begin{array}{l}\text { Dactylorhiza } \\
\text { traunsteinerioides }\end{array}$} & 1 & 1 & 1 \\
\hline $\mathrm{T} 2$ & & 1 & 1 & 1 \\
\hline $\mathrm{T} 3$ & & 1 & - & - \\
\hline $\mathrm{T} 4$ & & 1 & - & - \\
\hline T5 & & 1 & 1 & 1 \\
\hline T6 & & 1 & - & - \\
\hline $\mathrm{T} 7$ & & 1 & - & 1 \\
\hline $\mathrm{T} 8$ & & 1 & - & - \\
\hline T9 & & 3 & 2 & 2 \\
\hline $\mathrm{T} 10$ & \multirow{4}{*}{$\begin{array}{l}\text { Dactylorhiza } \\
\text { ebudensis }\end{array}$} & 4 & - & 1 \\
\hline T11 & & 2 & - & 2 \\
\hline $\mathrm{T} 12$ & & 2 & 2 & 1 \\
\hline $\mathrm{T} 13$ & & 2 & 1 & 4 \\
\hline
\end{tabular}

Table 2 Numbers of observed individuals on each turf each year. Note the 2012 figure was taken on 4 May 2012, so more plants may emerge in summer 2012.

In general plants have been pest free. At present, no additional nutritional additives have been employed to modify the microhabitats. It is intended to foliar-feed them with a dilute organic extract of seaweed so as not to upset the balance between the orchid and 
the fungi. It is known that high levels of nitrogen can cause fungi to become too vigorous and orchids can suffer and die off as victims of parasitism (Mitchell, 1993). Another good layer of sphagnum moss will be added to the turves for water retention. Plants will be cross-pollinated by hand and seed harvested from all plants flowering this year.

In 2011 leaf material from the three different populations of $D$. traunsteinerioides was donated to the DNA barcoding project at RBGE. Seed donations and collection data for D. ebudensis, D. traunsteinerioides and Platanthera bifolia were lodged with Royal Botanic Gardens, Kew and The Millennium Seed Bank.

\section{IN VITRO PROPAGATION}

In order to compare symbiotic versus asymbiotic propagation for raising Dactylorhiza ebudensis and D. traunsteinerioides and determine which of the two methods was more successful, we used three known universal fungal symbionts obtained from RBG Kew cultures. Two other orchid species were included in the trial as a control: the common $D$. purpurella, and Platanthera bifolia, a UK Biodiversity Action Plan species.

Seeds from Dactylorhiza ebudensis and D. traunsteinerioides were harvested from the ex situ turves at RBGE on 9 September 2010, seeds from Platanthera bifolia were harvested near Loch Leven, in Kinross, on 20 August 2010 and seeds from D. purpurella on 21 August 2010 at RBGE from plants in the alpine collection.

Capsules were labelled and stored following Thompson (1977) methods in a desiccator at room temperature $\left(20^{\circ} \mathrm{C}\right)$ with a saturated solution of calcium chloride. This solution at this temperature reduces the humidity level of the seed to around 5-6 per cent, which is the optimum for seed storage. After four days, when seeds were optimally dry, they were cleaned following methods described by Seaton \& Ramsey (2005). Prior to sowing, seeds were sterilised by soaking them in 0.1 per cent sodium hypochlorite solution and a drop of detergent for 20 minutes. Sterile deionised water was used to rinse the seeds and help to wash any sodium chloride away (Seaton \& Ramsey, 2005).

Each orchid species was cultured with each of the three fungi, plus one standard asymbiotic growth medium (Table 3), used as a control. The symbiotic media were prepared with a basic receipt recommended by Clements et al. (1986) (Table 3). The

\begin{tabular}{|l|l|l|l|}
\hline \multicolumn{2}{|c|}{ Asymbiotic media } & \multicolumn{2}{c|}{ Symbiotic media } \\
\hline $20 \mathrm{~g} / \mathrm{l}$ & Sucrose & $3.5 \mathrm{~g} / 1$ & Powdered oats \\
$1 \mathrm{~g} / \mathrm{l}$ & Charcoal & $0.1 \mathrm{~g} / \mathrm{l}$ & Yeast extract \\
$6 \mathrm{~g} / \mathrm{l}$ & Agar & $6 \mathrm{~g} / 1$ & Agar \\
$25 \mathrm{mls} / 1$ & Pineapple juice & & \\
$28 \mathrm{mls} / 1$ & Minerals (macro and micro) & \multicolumn{2}{|l}{} \\
\cline { 3 - 4 } $0.75 \mathrm{mls} / 1$ & Seaweed extract & \multicolumn{2}{|l}{} \\
\cline { 3 - 4 } & &
\end{tabular}

Table 3 Asymbiotic and symbiotic media recipes. 
medium previously autoclaved was poured under the laminar flow into sterile plastic petri dishes $(9 \mathrm{~cm}$ diameter) and allowed to set. The symbiotic medium was inoculated with $5 \mathrm{~mm}$ squares of fungus for each of the three species. Between four and six replicates were produced per species (Table 4). Between 25 and 200 seeds were sown on the set medium with a glass rod, and it was attempted to place the seeds in rows to facilitate scoring.

Cultures were sealed with laboratory film, arranged in trays and grown in the dark in a growing cabinet at a constant temperature of $18^{\circ} \mathrm{C}$. Seed germinations were examined under a light microscope monthly for a period of three months and scored to a standardised germination stage scale of 0-5 (Muir, 1986; Clements et al., 1986) (Table 6). Germination was considered to have taken place when a rupture of the seed coat was noticed.

Observations were continued beyond this to monitor asymbiotic germinations, as they tend to take longer. After three months, means (+/- standard error) of total germinations were worked out for each of the treatments to determine whether the differences between treatments were significant.

\begin{tabular}{|l|l|l|l|}
\hline Code & Isolate species & \multicolumn{1}{|c|}{ Host orchid/life cycle-stage } & \multicolumn{1}{c|}{ Origin/donor } \\
\hline F550 & $\begin{array}{l}\text { Cerotobasidium } \\
\text { cornigerum }\end{array}$ & Unknown & $\begin{array}{l}\text { International Mycological Institute } \\
\text { (IMI) culture collection }\end{array}$ \\
\hline F414 & Rhizoctonia sp. & Dactylorhiza iberica (mature stage) & RBG Kew alpine collection \\
\hline F21 & Tulasnella sp. & Liparis sp. (seed germinating stage) & RBG Kew fungi culture collection \\
\hline
\end{tabular}

Table 4 Fungal isolates used to inoculate the symbiotic media.

\section{Results}

The results from the trials after three months showed a clear higher percentage of germinations in symbiotic versus asymbiotic treatments (Table 6). Ceratobasidium cornigerum fungus (F550) promoted the highest percentage of germinations in Platanthera bifolia, Dactylorhiza ebudensis and D. purpurella, and Tulasnella sp. fungus (F21) in D. traun-

\begin{tabular}{|c|l|}
\hline Stage number & Visible evidence \\
\hline $\mathbf{0}$ & No germination \\
\hline $\mathbf{1}$ & Germination of seed with rupture of testa \\
\hline $\mathbf{2}$ & Production of rhizoids \\
\hline $\mathbf{3}$ & Appearance of leaf primordium \\
\hline $\mathbf{4}$ & Production of first chlorophyllous leaf \\
\hline $\mathbf{5}$ & Production of root initial \\
\hline
\end{tabular}

Table 5 Seed development stages and visible evidence of the stages reached (Muir, 1986; Clements et al., 1986). 
steinerioides. However, F21 appeared to stimulate plants to reach the most advanced protocorm stages (Table 6) in D. purpurella (stage 4), D. traunsteinerioides (stage 3) and Platanthera bifolia (stage 2). D. ebudensis reached its furthest development with F550 (stage 2). Asymbiotic germinations after three months were very low in all orchids with a maximum stage 2 being reached in Platanthera bifolia, D. traunsteinerioides and D. purpurella and with no germinations (stage 0) in D. ebudensis. Table 5 describes the development stage numbering and corresponding visible evidence of these.

\begin{tabular}{|l|l|l|l|l|l|l|l|l|}
\hline & \multicolumn{2}{|c|}{ Platanthera bifolia } & \multicolumn{2}{c|}{$\begin{array}{c}\text { Dactylorhiza } \\
\text { ebudensis }\end{array}$} & \multicolumn{2}{c|}{$\begin{array}{c}\text { Dactylorhiza } \\
\text { traunsteinerioides }\end{array}$} & \multicolumn{2}{c|}{$\begin{array}{c}\text { Dactylorhiza } \\
\text { purpurella }\end{array}$} \\
\hline & & Stage & & Stage & & Stage & & Stage \\
\hline F550 & $18.8 \% \pm 2.75$ & 1 & $24.01 \% \pm 9.49$ & 2 & $36.16 \% \pm 10.44$ & 1 & $80.45 \% \pm 3.79$ & 2 \\
\hline F21 & $8.52 \% \pm 1.63$ & 2 & $0 \% \pm 0$ & 0 & $42.76 \% \pm 12.05$ & 3 & $28.40 \% \pm 3.69$ & 4 \\
\hline F414 & $3.90 \% \pm 0.84$ & 1 & $2.98 \% \pm 1.78$ & 1 & $9.56 \% \pm 4.17$ & 1 & $16.11 \% \pm 2.69$ & 2 \\
\hline Asymbiotic & $1.00 \% \pm 0.39$ & 2 & $0 \% \pm 0$ & 0 & $2.85 \% \pm 1.45$ & 3 & $1.10 \% \pm 1.10$ & 2 \\
\hline
\end{tabular}

Table 6 Germination trial results after three months, showing percentage germinations (mean \pm standard error) and development stage reached in symbiosis (see Table 5).
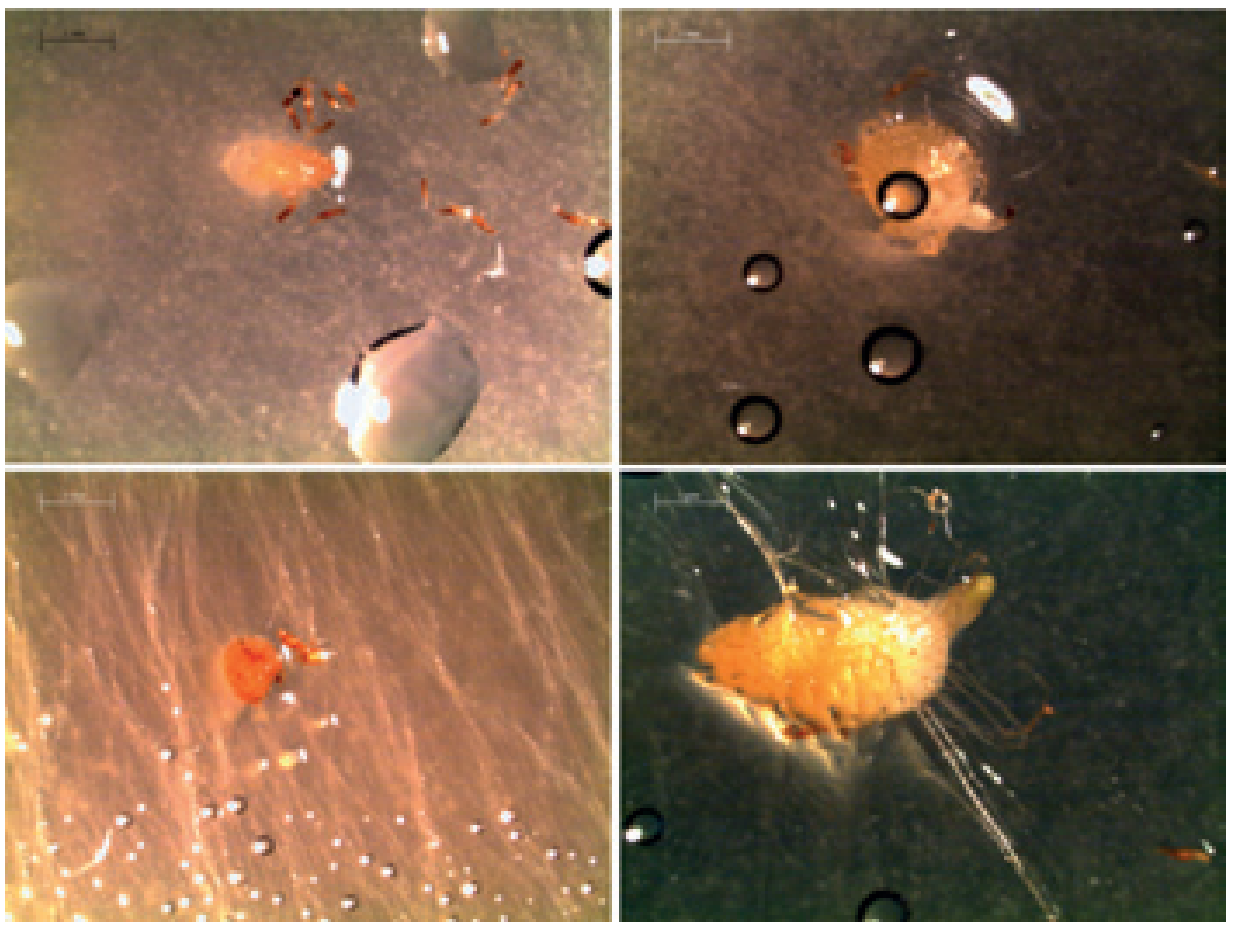

Fig. 6 Effect of $\mathrm{f} 21$ on each species: (top left) Platanthera bifolia reached stage 2; (top right) Dactylorhiza traunsteinerioides reached stage 3; (bottom left) Dactylorhiza ebudensis reached stage 2; and (bottom right) Dactylorhiza purpurella reached stage 4 . All photos have a $1 \mathrm{~mm}$ scale bar and were taken with the same magnification. Photo: Berta Millàs Xancó. 


\section{Discussion}

Seed germinations occurred in almost every treatment, except for Dactylorhiza ebudensis, which did not germinate in asymbiotic media or with symbiont F21. Otherwise each universal fungus supported germinations in D. traunsteinerioides, D. purpurella and Platanthera bifolia; with F21 promoting their further seedling development stage (see Fig. 6).

Germinations are indeed more prevalent in symbiotic treatments than asymbiotic treatments. Symbiotic germinations did not show much difference between month 2 and month 3 observations. Eight weeks is sufficient time to assess whether the symbionts have been compatible or not. However, observations were carried out for a further three months and it was apparent that symbiotic germinations seldom advanced beyond stage 3. This suggests that the universal fungi can promote germination, but a partner-switch may be required to support plants in later developmental stages. The prolonged observation showed that asymbiotic germinations are slower, ultimately producing 10.3 per cent germination in D. purpurella and 18.05 per cent in D. traunsteinerioides. In both of these cases, plants have reached stage 4 , but will require subculture and prolonged periods of acclimatisation if they are to be cultivated in standard pots and grown outside. This is also the case for protocorms reaching stage 4 with $\mathrm{f} 21$ for these same species.

Platanthera has proved difficult to cultivate in the past due to strong dormancy mechanisms (Rasmussen, 1995). In this experiment, germination occurred and reached stage 2 (Muir, 1986). However, stage 2 is sometimes only induced by fungal contact and the fungus may become parasitic beyond this stage. This may have been the case in P. bifolia, as no germinations reached stage 3 within the observation period. Ceratobasidium (F550) appeared to do this in D. traunsteinerioides as well, with high germinations ( 36.16 per cent) and apparent initial symbioses shifting to pathogenesis. The fungus grew vigorously out of control for the orchid.

The rare Scottish endemic D. ebudensis, which is highly specialised and confined to Machair soils, did poorly in all treatments - this may be due to a tighter obligate symbiosis with a more specialised fungal partner adapted to the dry Machair. Consequently, it is particularly important to find the wild symbionts of this plant.

Broadly speaking, for orchid conservation basic research into the natural life cycle of species of interest and wild partners should be carried out. If no information is available, it is recommended to try both methods, asymbiotic and symbiotic, simultaneously (Seaton et al., 2012). In order to capture orchid-specific fungi, packets containing seeds of the two target species (D. ebudensis and D. traunsteinerioides) were buried in the respective field sites in October 2010 and harvested in November 2011, with a repeat set reburied at the same time. The intention for these is to capture specific fungal associates at the germination stage and/or seedling stage. 


\section{CONCLUSIONS}

Although it might seem radical to remove entire plants and surrounding turf for rare orchids, this has proved to be a successful method of establishing an ex situ population. Removal of the plants is only possible in those populations where there are enough individuals to cope with the loss, in this case $>100$ individuals.

Although labour-intensive, it is evident that a combination of turf removal and micropropagation (both symbiotic and asymbiotic) is ideal, allowing orchids to be conserved and studied ex situ, as well as uncovering further information about their life cycles, which is a key component in their successful micropropagation. Developing these micropropagation techniques is essential for populations and species that are too few in number to support turf removal programmes. Isolation of wild fungal partners using seed trapping methods is also essential to these efforts in order to develop speciesspecific ex situ micropropagation protocols. The ex situ turf populations provide a ready supply of seed for such trapping experiments.

This method has been successful for D. ebudensis. Putative symbiotic fungal cultures have been isolated from wild seed-capture experiments and will be used for symbiotic germination and the fungi characterised using DNA sequences. This can then be compared with fungi isolated directly from adult plants in the turf cultures. Findings will be reported in a future paper.

\section{ACKNOWLEDGEMENTS}

This project was supported by the Sibbald Trust and William Steele Trust from RBGE, whom we would like to thank. We wish also to thank Scottish Natural Heritage for allowing permission to uproot plants and to collect and sow seeds in the different locations. We are also grateful to the landowners for their permission to do this on their sites. We thank Stephen Bungard and Frank Horsman for their expertise in locating and identifying the targeted species and RBG Kew for providing the fungal isolates and training in symbiotic microproagation techniques. Thanks are also due to Richard Pankhurst and Phil Lusby from RBGE for their precious help in the initial planning of the project and to David Knott, David Rae and Mary Gibby for the support required to carry out this project. We thank Frieda Christie, Ruth McGregor and Michelle Hollingsworth for their technical support with all the laboratory equipment at RBGE, and Peter Brownless and Natacha Frachon in the nursery at RBGE. Andy Scobie from SNH provided seeds of Spiranthes romanzoffiana for future sowings. We are also grateful to Richard Warren for his technical advice in orchid micropropagation, Mike Hughes from Durham Botanical Gardens for his inspiration and support and Mariona Estorach Rius for her valuable help in the next stage of this project. We especially thank Sheena McKendrick for her technical recommendations and for sharing her knowledge with us. Finally our most sincere and warmest acknowledgements go to Grace Prendergast, for her continuous invaluable help both technical and knowledgeable. 


\section{REFERENCES}

BIDARTONDO, M.I. \& READ, D.J. (2008). Fungal specificity bottlenecks during orchid germination and development. Molecular Ecology 17, 3,707-3,716.

BONNARDEAUX, Y., BRUNDRETT, M., BATTY, A., DIXON, K., KOCH, J. \& SIVASITHAMPARAM, K. (2007). Diversity of mycorrhizal fungi of terrestrial orchids: compatibility webs, brief encounters, lasting relationships and alien invasions. Mycological Research, 11(1), 51-61.

BRUNDRETT, M.C. (2007). Role of symbiotic relationships in Australian terrestrial orchid conservation. Australian Plant Conservation, 15, 2-7.

BURNEY, D. (2009). Are we naïve to think we can save rare plants from extinction? Sibbaldia, 7, 61-76.

CLEMENTS, M.A., MUIR, H. \& CRIBB, P.J. (1986). A preliminary report on the symbiotic germination of European terrestrial orchids. Kew Bulletin, 41, 437-445.

CRIBB, P.J., KELL, S.P., DIXON, K.W. \& BARRETT, R.L. (2003). Orchid conservation: a global perspective. In: DIXON, K.W., KELL, S.P., BARRETT, R.L. \& CRIBB, P.J. (eds). Orchid Conservation. Natural History Publications, 1-24. Kota Kinabalu, Sabah.

CURTIS, J.T. (1939). The relation of specificity of orchid mycorrhizal fungi to the problem of symbiosis. American Journal of Botany, 26, 390-399.

HARRAP, A. \& HARRAP, S. (2009). Orchids of Britain \& Ireland. A Field and Site Guide, 2nd edn. A \& C Black Publishers Ltd, London.

MCKENDRICK, S.L., LEAKE, J.R., TAYLOR, D.L. \& READ, D.J. (2000). Symbiotic germination and development of myco-heterotrophic plants in nature: ontogeny of Corallorhiza trifida and characterization of its mycorrhizal fungi. New Phytologist, 145, 523-537.

MITCHELL, R.B. (1989). Growing hardy orchids from seeds at Kew. The Plantsman, 2 , 152-169.

MITCHELL, R.B. (1993). Dactylorhizas from seed. Bulletin of the Alpine Garden Society, 61(3), 324-330.

MUIR, H.J. (1989). Germination and mycorrhizal fungus compatibility in European orchids. In: PRITCHARD, H.W. (ed.). Modern Methods in Orchid Conservation: The Role of Physiology, Ecology and Management. Cambridge University Press, Cambridge.

RAE, D. (ed.) (2006). Collection Policy for the Living Collection. Royal Botanic Garden Edinburgh.

RASMUSSEN, H.N. (1995). Terrestrial Orchids: From Seed to Mycotrophic Plant. Cambridge University Press, Cambridge.

RASMUSSEN, H.N. \& WHIGHAM, D.F. (1993). Seed ecology of dust seeds in situ: A new study technique and its application in terrestrial orchids. American Journal of Botany, 80(12), 1,374-1,378.

SEATON, P. \& RAMSEY, M. (2005). Growing Orchids from Seed. Royal Botanic Gardens, Kew. Kewgrowing, Surrey. 
SEATON, P., CRIBB, P., RAMSEY, M. \& HAGGER, J. (2012). Growing Hardy Orchids. Royal Botanic Gardens, Kew. Kewgrowing, Surrey.

SINGLE, J. \& SINGLE, S. (2010). Short Note: Good roots matter from day one. Sibbaldia, 8 , $179-188$.

SWARTS, N.D. \& DIXON, K.W. (2009). Terrestrial orchid conservation in the age of extinction. Annals of Botany, 104, 543-556.

SWARTS, N.D., SINCLAIR, E.A., FRANCIS, A. \& DIXON, K.W. (2010). Ecological specialization in mycorrhizal symbiosis leads to rarity in an endangered orchid. Molecular Ecology, 19, 3,226-3,242.

THOMPSON, P.A. (1977). Orchids from Seed. HMSO, London.

VERMEULEN, P. (1947). Studies on Dactylorchids. Schotanus \& Jens, Utrecht.

WALTER, K.S. \& O'NEAL, M.J. (1985-2010). BG-BASE ${ }^{\mathrm{TM}}$ (Collection Management Software). BG-BASE Inc. \& BG-BASE (UK) Ltd.

WATERMAN, R.J. \& BIDARTONDO, M.I. (2007). Deception above, deception below: linking pollination and mycorrhizal biology of orchids. Journal of Experimental Botany, 59(5), $1,085-1,096$.

YODER, J.A., ZETTLER, L.W. \& STEWART, S.L. (2000). Water requirements of terrestrial and epiphytic orchid seeds and seedlings, and evidence for water uptake by means of mycotrophy. Plant Science, 156, 145-150. 